
cited.

\title{
ASAS KESEIMBANGAN DALAM ALTERNATIF PENYELESAIAN SENGKETA HUBUNGAN INDUSTRIAL DI LUAR PENGADILAN
}

\section{Usak}

(Dosen Hukum Bisnis, Program Studi Ilmu Hukum Fakultas Ilmu Sosial dan Humaniora Universitas Halmahera. Meraih Sarjana Hukum (S.H) Fakultas Hukum Universitas Kristen Indonesia Paulus (2006) dan Magister Hukum (M.H) Fakultas Hukum Universitas Kristen Satya Wacana (2015)). (E-mail: usakhalmahera@yahoo.com)

Received: 28 Juni 2018; Accepted: 27 Mei 2019; Published: 30 Juni 2019

\begin{abstract}
:
Industrial labor disputes between workers or workers and employers often occur as a result of mismatches of opinion and / or actions of both. Both disputes are usually preceded by violations of law and may occur not for violation of the law. For the right institution to resolve industrial relations disputes, if based on the principle of balance thinking is a deliberation to seek dispute resolution, the right institution is a non-litigation institution outside the court, without having to be brought to the Industrial Relations Court. To further ensure the creation of a balance principle for the parties in disputes in industrial relations disputes, according to Law no. 2 of 2004 on Industrial Relations Dispute Settlement, dispute settlement takes priority through negotiation to seek deliberation outside the consensus of the courts, this will create a balance principle for the position of the parties while providing legal protection for workers/laborers. In accordance with the legal matter, the purpose of this study is to examine alternative forms of realization of industrial relations dispute settlement outside the court as a reflection of the principle of equilibrium.
\end{abstract}

Keywords: balance principle, alternative dispute settlement, industrial relations.

\section{Pendahuluan}

\section{A. Latar Belakang}

Perselisihan hubungan industrial dapat dikurangi atau bahkan diantisipasi, bila pekerja dan pengusaha melaksanakan hak dan kewajibannya sesuai dengan regulasi yang berlaku. Namun, dari sisi regulasi sering menimbulkan permasalahan krusial bagi pekerja/buruh dan atau pengusaha. Ketika masalah itu diselesaikan oleh lembaga peradilan pun, masih menyisakan ketidakpuasan salah satu pihak atau dapat juga menciptakan rasa ketidakadilan baru bagi pihak lain. Apalagi, bila para pihak menggunakan cara terakhir, yaitu lock out bagi pengusaha dan mogok kerja bagi serikat pekerja. Meskipun pelaksanaannya telah sesuai dengan regulasi, namun dampaknya dapat mengganggu stabilitas perekonomian nasional. 
Kelangsungan suatu hubungan kerja diperlukan oleh para pihak, pekerja dan pengusaha. Suatu mekanisme yang damai dan memiliki asas keseimbangan diperlukan untuk menyelesaikan perselisihan di antara mereka, karena para pihak memiliki suatu kepentingan yang tinggi dalam hubungan mereka. Di satu pihak, pengusaha sebagai pebisnis menginginkan untuk memperoleh keuntungan sebanyak mungkin dari usahanya. Di lain pihak, pekerja menginginkan upah setinggi-tingginya dari pekerjaan yang dilakukan untuk membiayai kebutuhan hidupnya. Kepentingan-kepentingan yang berbeda tersebut seringkali membuat para pihak dalam suatu posisi yang berbeda dan menjadikan mereka pada kondisi yang saling bertentangan dan tidak seimbang.

Menurut WJS. Poerwadiminta memberikan arti keseimbangan dalam Kamus Umum Bahasa Indonesia adalah keadaan seimbang. ${ }^{1}$ Secara umum dapat dikatakan bahwa keseimbangan adalah suatu keadaan dimana terdapat keserasian atau keharmonisan, dan tidak dalam

\footnotetext{
${ }^{1}$ WJS.Poerwadarminta, Kamus Umum Bahasa Indonesia (Jakarta: PN.Balai Pustaka, 1976), 375.
}

kecenderungan berat sebelah atau condong pada hal tertentu, dengan memperhatikan proporsional masingmasing komponen-komponen yang melingkupinya. Dalam hubungan industrial, keseimbangan hubungan antara pengusaha dan buruh merupakan salah satu kunci utama menghadapi tantangan ekonomi di masa depan.

Hubungan industrial adalah suatu sistem hubungan yang terbentuk antara para pelaku dalam proses produksi barang dan/atau jasa yang terdiri dari unsur pengusaha, pekerja/buruh, dan pemerintah yang didasarkan pada nilai-nilai Pancasila dan Undang-Undang Dasar Negara Republik Indonesia Tahun $1945 .^{2}$ Konteks asas keseimbangan hubungan industrial, termuat dalam konstitusi Pasal 28 D ayat (2) UUD 1945 perubahan kedua yang berbunyi : "setiap orang berhak untuk bekerja serta mendapat imbalan dan perlakukan yang adil dan layak dalam hubungan kerja".

Secara filosofi hubungan antara pengusaha dan pekerja bagaikan sekeping mata uang, interaksinya tidak

\footnotetext{
2 Pasal 1 angka 16 Undang-Undang Nomor 13 Tahun 2003 Tentang Ketenagakerjaan.
} 
dapat dipisahkan dan diwujudkan

ketidakseimbangan

hubungan

dalam bentuk hubungan kerja.

industrial. Tidak dipenuhinya hak para

Hubungan kerja adalah hubungan

antara pengusaha dengan

pekerja/buruh berdasarkan perjanjian

kerja, yang mempunyai unsur

pekerjaan, upah, dan perintah. ${ }^{3}$

Hubungan kerja biasanya termuat

dalam perjanjian kerja. Dalam kontrak

yang berlandaskan keadilan dimaknai

sebagai suatu hubungan timbal-balik

(kontraktual) dimana posisi para

pihaknya (subyeknya) dalam

menentukan hak kehendaknya

(wilsrecht) diupayakan selalu

seimbang dalam menentukan hak dan

kewajibannya. Oleh karena itu, apabila

terdapat posisi yang tidak seimbang di

antara para pihak, maka hal ini harus

ditolak karena akan berpengaruh pada

substansi maupun isi maksud dan tujuan dibuatnya suatu perjanjian. ${ }^{4}$

Isu hukum yang sering terjadi adalah permasalahan kontrak kerja, pemutusan hubungan kerja, tidak dibayarnya uang intensif, keterlambatan pembayaran uang pensiun merupakan potret klasik

\footnotetext{
${ }^{3}$ Pasal 1 angka 15 Undang-Undang Nomor 13 Tahun 2003 Tentang Ketenagakerjaan.

4 Agus Yudha Hernoko, Hukum Perjanjian Asas Proposionalitas dalam Kontrak Komersial (Jakarta: Kencana Prenada Media Group, 2010), 83.
}

menjadi perbedaan pendapat, bahkan bertendensi menimbulkan potensi sengketa hubungan industrial.

Menurut Harijanto ${ }^{5}$ menyatakan bahwa sengketa atau perselisihan pendapat dapat terjadi kapanpun dan dimanapun tanpa dibatasi ruang dan waktu selama kita hidup bermasyarakat. Baik sengketa yang bersifat perorangan maupun sengketa yang bersifat sengketa publik. Yang terpenting dalam hal sengketa atau perselisihan ini adalah bagaimana cara untuk dapat menyelesaikan sengketa tersebut secarabijaksana, damai dan beradab, sehinggasengketa atau perselisihan tersebut tidaksampai membesar yang menimbulkan pertumpahan darah yang pada akhirnya akan merugikan semua pihak.

Untuk lebih menjamin terciptanya asas keseimbangan dan rasa keadilan bagi pihak yang beperkara dalam sengketa hubungan industrial, menurut UU No 2 Tahun

\footnotetext{
5 Harijanto, "Analisis Terhadap Alternatif Penyelesaian Sengketa (APS) Ditinjau Dari Sosiologi Hukum," Jurnal Rechtens, Volume 1, Nomor 2 (Desember 2014) : 57.
} 


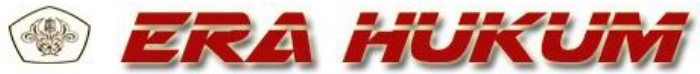 \\ Vol. 16, No. 2, Oktober 2018}

2004

tentang

Penyelesaian

Perselisihan Hubungan Industrial,

penyelesaian sengketa diutamakan

melalui perundingan guna mencari

musyawarah mufakat di luar

pengadilan. Untuk itu penulis tertarik

untuk melakukan penelitian yang

berkaitan dengan proses penyelesaian

perselisihan hubungan industrial

dalam hubungan kerja antara

pekerja/buruh dengan pemberi kerja.

\section{B. Rumusan Masalah}

Berdasarkan latar belakang tersebut, maka yang menjadi permasalahan yang akan diteliti adalah bagaimana bentuk perwujudan alternatif penyelesaian sengketa hubungan industrial di luar pengadilan sebagai cerminan asas keseimbangan?

\section{Tujuan Penelitian}

Untuk mengkaji bentuk perwujudan alternatif penyelesaian sengketa hubungan industrial di luar pengadilan sebagai cerminan asas keseimbangan.

\section{Metode Penelitian}

Metode yang digunakan dalam penelitian ini adalah penelitian hukum normatif melalui pendekatan
Usak Asas Keseimbangan Dalam Alternatif Penyelesaian Sengketa...

konseptual (concept approach).

Menurut Peter Mahmud Pendekatan konseptual dilakukan manakala peneliti tidak beranjak dari aturan hukum yang ada. ${ }^{6}$

\section{Pembahasan}

\section{A. Asas Keseimbangan}

Dalam kerangka norma hukum, asas dapat dimaknai sebagai suatu yang diyakini kebenarannya yang dijadikan pokok atau dasar dari penyusunan norma-norma hukum, baik tertulis maupun yang tidak tertulis. Asas itu sendiri tidak selalu dirumuskan dalam ketentuanketentuan suatu peraturan, namun keberadaannya selalu diakui dan dijadikan sandaran dari ketentuanketentuan hukum tersebut.

Beberapa tokoh filsuf dan ahli hukum mengaitkan masalah keseimbangan dengan keadilan. Plato sebagaimana dikutip oleh Theo Huijbers $^{7}$ menggambarkan keadilan pada jiwa manusia dengan membandingkannya dengan kehidupan negara, mengemukakan

\footnotetext{
${ }^{6}$ Peter Marzuki Mahmud, Penelitian Hukum (Jakarta: Penerbit Kencana Prenada Media Group, 2005), 177.

7 Theo Huijbers, Filsafat Hukum Dalam Lintasan Sejarah (Yogyakarta: Kanisius, 1986), 23.
} 
bahwa jiwa manusia terdiri atas tiga bagian, yaitu pikiran (logistikon), perasaan dan nafsu baik psikis maupun jasmani (epithumatikon), rasa baik dan jahat (thumoeindes). Jiwa itu teratur secara baik bila dihasilkan suatu kesatuan yang harmonis antara ketiga bagian itu. Keadilan terletak dalam batas yang seimbang antara ketiga bagian jiwa sesuai dengan wujudnya masing-masing.

Aristoteles memberikan arti keadilan sebagai, "ius suum cuique tribuendi" adalah memberikan masing-masing bagiannya. ${ }^{8}$

Selanjutnya keutamaan yang disebut keseimbangan menurut Thomas Aquinas menentukan bagaimana hubungan orang dengan orang lain dalam hal iustum, yakni mengenai 'apa yang sepatutnya bagi orang lain menurut sesuatu kesamaan proporsional' (aliquod opus adaequatum alteri secundum aliquem aequalitatis modum). ${ }^{9}$

Roscoe Pound, seorang pakar hukum Amerika mengatakan bahwa Hukum menjamin social cession (keterpaduan sosial) dan perubahan tertib sosial dengan cara

${ }^{8}$ L.J. Van Apeldoorn, Pengantar Ilmu Hukum (Jakarta:Pradnya Paramita, 1983), 23.

${ }^{9}$ Theo Huijebers, Op.cit, hal 42. menyeimbangkan konflik kepentingan yang mencakup: ${ }^{10}$

a. kepentingan-kepentingan

individual;

b. Kepentingan-kepentingan

sosial (yang timbul dari kondisi-kondisi umum kehidupan sosial); dan

c. kepentingan-kepentingan publik (khususnya kepentingan negara).

John Rawls ${ }^{11}$ menyatakan bahwa prinsip-prinsip keseimbangan diperoleh bukan dengan mengevaluasi kemanfaatan dari tindakan-tindakan melainkan dari pilihan rasional di dalam kondisi adil. Prinsip-prinsip tersebut dilekatkan pada struktur dasar masyarakat, bukannya setiap tindakan atau setiap tingkatan di mana keadilan dipersoalkan. Teori keadilan Rawls, menggunakan kontrak sosial sebagai basis teori keadilan. Prinsip-prinsip Rawls melindungi pihak-pihak yang paling kurang beruntung di masyarakat. Tidak ada pertukaran kebebasan atau kesejahteraan mereka

${ }^{10}$ Roger Cotterrell, The Sociology of Law: An Introduction (London: Butterworths, 1992), 76.

11 Karen Lebacqz, Teori-teori Keadilan (Six Theories of Justice), (Bandung: Nusa Media, 1986),. 49-79. 
dengan kesejahteraan orang lain yang

dibolehkan. Kebebasan-kebebasan dasar harus didistribusikan setara dan tidak boleh dikorbankan demi pencapaian ekonomi.

Dari pengertian dan pendapat para ahli filsuf maupun ahli hukum di atas, dapat ditarik suatu kesimpulan, bahwa asas keseimbangan merupakan perpaduan antara beberapa komponen yang menjadi dasar dari keserasian, dan senantiasa mengandung unsur keadilan, yang diletakkan secara proporsional, yang apabila salah satu komponen diabaikan atau terganggu, maka akan mengakibatkan ketidakadilan.

\section{B. Hubungan Industrial}

Undang-Undang Nomor 13

Tahun 2003 mengartikan hubungan industrial, adalah suatu sistem hubungan industrial yang terbentuk antara para pelaku dalam proses produksi barang dan/ atau jasa yang terdiri dari unsur pengusaha, pekerja/ buruh, dan pemerintah yang didasarkan pada nilai-nilai Pancasila dan Undang-Undang Dasar Negara Republik Indonesia tahun $1945 .{ }^{12}$ Hubungan industrial juga dikenal

12 Pasal 1 angka 16 Undang-Undang Nomor 13 Tahun 2003 Tentang Ketenagakerjaan.

3 Imam Soepomo, Hukum Perburuhan Bidang Hubungan Kerja, (Jakarta: Penerbit Jambatan, 1975), 6-7. 
diselesaikan dengan sebaikbaiknya.

Hubungan Industrial terbentuk dengan mengacu pada landasan falsafah bangsa dan negara, yang karena setiap bangsa dan negara mempunyai falsafah yang berbeda maka system hubungan industrialnya pun cenderung untuk berbeda antara satu negara dengan negrara lainnya. Indonesia dengan Pancasila dan Undang-Undang Dasar Negara Republik Indonesia tahun 1945 sebagai falsafah bangsa dan negara, maka hubungan industrial pun mengacu pada Pancasila dan UndangUndang Dasar Negara Republik Indonesia tahun 1945. Untuk itu tujuan, pokok-pokok pikiran, asasasas, dan norma-norma dari aturan hukum yang mengatur hubungan industrial di Indonesia haruslah sebagai berikut $:^{14}$

1) Tujuan Hubungan Industrial

Mengacu pada Pembukaan UUD 1945 perihal Cita-cita Proklamasi Kemerdekaan Negara Kesatuan Republik Indonesia yaitu untuk

14 Suherman Toha, dkk, Laporan Akhir Penelitian Hukum Tentang Penyelesaian Perselisihan Hubungan Industrial, ( Jakarta: Badan Pembinaan Hukum Nasional Kementerian Hukum Dan Ham RI, 2010), 3437. mewujudkan masyarakat adil dan makmur yang berdasarkan Pancasila serta ikut melaksanakan ketertiban dunia yang berdasarkan kemerdekaan, perdamaian adadi dan keadilan sosial. Maka hubungan industrial, melalui penciptaan ketenangan, ketentraman dan ketertiban kerja serta ketenangan usaha, meningkatkan produksi, dan meningkatkan kesejahteraan pekerja serta derajatnya sesuai martabat manusia.

2) Pokok-pokok Pikiran Hubungan Industrial

Dengan mengacu pada Pancasila sebagai landasan filosofis maka Hubungan Industrial Pancasila harus tumbuh kembang dengan pengimplementasian pokokpokok pikiran dari nilai-nilai Pancasila yang adalah:

a. Hubungan Industrial Pancasila didasarkan atas keseluruhan sila-sila dari pada Pancasila secara utuh dan bulat yang tidak dapat dipisahkan satu sama lainnya;

b. Hubungan Industrial Pancasila meyakini bahwa kerja bukanlah hanya sekedar 
mencari nafkah, akan tetapi

kerja sebagai pengabdian

manusia kepada Tuhan Yang

Maha Esa;

c. Dalam Hubungan Industrial Pancasila pekerja bukan hanya dianggap sebagai faktor produksi belaka, akan tetapi sebagai manusia pribadi sesuai dengan harkat, martabat dan kodratnya;

d. Dalam Hubungan Industrial Pancasila pengusaha/ majikan dan pekerja/ buruh tidak dibedakan karena golongan, keyakinan, politik, paham, aliran, agama, suku maupun jenis kelamin. Karena Hubungan Industrial Pancasila berupaya mengembangkan orientasi kepada kepentingan nasional;

e. Sesuai dengan prinsip musyawarah dan mufakat maka Hubungan Industrial Pancasila menghilangkan perbedaan-perbedaan dan mengembangkan persamaanpersamaam dalam rangka menciptakan keharmonisan antara pekerja dan pengusaha. Hubungan Industrial
Pancasila meyakini setiap perbedaan pendapat, dan perselisihan yang timbul harus diselesaikan secara musyawarah untuk mufakat dan tidak diselesaikan dengan cara pemaksaan oleh satu pihak kepada pihak lain;

f. Dalam Hubungan Industrial Pancasila didorong untuk terciptanya keadilan sosial bagi seluruh rakyat Indonesia, dan untuk itu seluruh hasil upaya perusahaan harus dapat dinikmati bersama oleh pengusaha dan pekerja secara serasi, seimbang, dan merata. Serasi dan seimbang dalam pengertian bahwa setiap pihak mendapat bagian yang memadai sesuai dengan fungsi dan prestasinya. Merata dalam pengertian bahwa setiap hasil perusahaan dapat dinikmati oleh seluruh anggota perusahaan.

3) Asas-Asas Hukum Hubungan Industrial

Dengan mengacu pada Pancasila sebagai landasan filosofis dan Undang-Undang Dasar 1945 sebagai landasan konstitusional, 
maka norma hukum hubungan kewajibannya di dalam proses industrial di Indonesia harus produksi.

mengandung asas-asas antara lain:

a. Asas manfaat dalam pengertian memberikan manfaat bagi buruh, pengusaha, pemerintah, serta masyarakat,

b. Asas usaha bersama dan kekeluargaan;

c. Asas demokrasi;

d. Asas keterbukaan ;

e. Asas adil dan merata;

f. Asas keseimbangan;

g. Asas kemitraan kerja.

4) Sikap dan Mentalitas Masyarakat Industrial

Untuk dapat dilaksanakannya asas-asas serta norma atau kaidah hukum hubungan industrial diperlukan dukungan segenap unsur masyarakat industrial. Untuk itu diperlukan sikap dan mentalitas masyarakat industrial yang berupa; kegotongroyongan, toleransi, tengggangrasa, bantumembantu dan mampu mengendalikan diri, saling hormat menghormati, saling mengerti kedudukan dan perannya masingmasing, memahami hak dan

\section{Sengketa Dalam Hubungan \\ Industrial}

Menurut Charles D. Drake sengketa dalam hubungan industrial antara pekerja/ buruh dengan pengusaha dapat terjadi karena didahului oleh pelanggaran hukum juga dapat terjadi karena bukan pelanggaran hukum. ${ }^{15}$ Perselisihan perburuhan yang terjadi akibat pelanggaran hukum pada umumnya disebabkan karena: ${ }^{16}$

1) Terjadi perbedaan paham dalam pelaksanaan hukum perburuhan. Hal ini tercermin dari tindakan pekerja/ buruh atau pengusaha yang melanggar suatu ketentuan hukum. Misalnya pengusaha tidak mempertanggungkan buruh/ pekerjanya pada program Jamsostek, membayar upah di bawah ketentuan standar minimum yang berlaku, tidak memberikan cuti dan sebagainya.

2) Tindakan pengusaha yang diskriminatif, misalnya jabatan,

15 Lalu Husni, Hukum Ketenagakerjaan Indonesia, (Jakarta: RajaGrafindo Persada, 2007), 42.

${ }^{16}$ Ibid. 
jenis pekerjaan, pendidikan, masa

kerja yang sama tapi karena perbedaan jenis kelamin lalu diperlakukan berbeda.

Sedangkan

perselisihan

perburuhan yang terjadi tanpa didahului oleh suatu pelanggaran, umumnya disebabkan oleh: ${ }^{17}$

1) Perbedaan dalam menafsirkan hukum perburuhan. Misalnya menyangkut cuti melahirkan dan gugur kandungan, menurut pengusaha buruh/ pekerja wanita tidak berhak atas cuti penuh karena mengalami gugur kandungan, tetapi menurut buruh/ serikat buruh hak cuti harus tetap diberikan dengan upah penuh meskipun buruh hanya mengalami gugur kandungan atau tidak melahirkan.

2) Terjadi karena ketidaksepahaman dalam perubahan syarat-syarat kerja, misalnya buruh/ serikat buruh menuntut kenaikan upah, uang makan, transport, tetapi pihak pengusaha tidak menyetujuinya.

Berdasarkan ketentuan Pasal 2 Undang-Undang No. 2 Tahun 2004 Tentang Penyelesaian Hubungan

${ }^{17}$ Ibid.
Industrial, bahwa jenis-jenis perselisihan hubungan industrial meliputi :

1) Perselisihan hak, yaitu perselisihan yang timbul karena tidak dipenuhinya hak, akibat adanya perbedaan pelaksanaan atau penafsiran terhadap ketentuan peraturan perundangundangan, perjanjian kerja, peraturan perusahaan, atau perjanjian kerja bersama.

2) Perselisihan kepentingan, yaitu perselisihan yang timbul dalam hubungan kerja karena tidak adanya kesesuaian pendapat mengenai pembuatan, dan/ atau perubahan syarat-syarat kerja yang ditetapkan dalam perjanjian kerja, atau peraturan perusahaan, atau perjanjian kerja bersama.

3) Perselisihan pemutusan hubungan kerja, yaitu perselisihan yang timbul karena tidak adanya kesesuaian pendapat mengenai pengakhiran hubungan kerja yang dilakukan oleh salah satu pihak.

4) Perselisihan antarserikat pekerja/serikat buruh, yaitu perselisihan antara serikat pekerja/ serikat buruh dengan serikat pekerja/ serikat buruh lain 
hanya dalam satu perusahaan, hak dan kewajiban karena tidak adanya persesuaian keserikatpekerjaan.

paham mengenai keanggotaan, pelaksanaan hak, dan kewajiban keserikatpekerjaan.

Dengan pertimbanganpertimbangan di atas, Undang-Undang No. 2 Tahun 2004 Tentang Penyelesaian Perselisihan Hubungan Industrial mengatur penyelesaian perselisihan hubungan industrial yang disebabkan oleh $:^{18}$

1) Perbedaan pendapat atau kepentingan mengenai keadaan ketenagakerjaan yang belum diatur dalam perjanjian kerja, peraturan perusahaan, perjanjian kerja bersama, atau peraturan perundang-undangan.

2) Kelalaian atau ketidakpatuhan salah satu atau para pihak dalam melaksanakan ketentuan normatif yang telah diatur dalam perjanjian kerja, peraturan perusahaan, perjanjian kerja bersama, atau peraturan perundang-undangan.

3) Pengakhiran hubungan kerja.

4) Perbedaan pendapat antarserikat pekerja/ serikat buruh dalam satu perusahaan mengenai pelaksanaan

18 Maimun, Hukum Ketenagakerjaan Suatu Pengantar, (Jakarta: PT Pradnya Paramita, 2007), 182.

\section{Upaya Pemerintah Dalam Mewujudkan \\ Asas}

Keseimbangan Hubungan

Industrial

Untuk terwujudnya

keseimbangan dalam hubungan industrial, pemerintah telah melakukan berbagai upaya. Upaya tersebut diaktualisasikan dengan cara mendamaikan para pihak untuk kebebasan berserikat dan upaya penyelesaian perselisihan hubungan industrial dalam rangka pencapaian stabilitas dan pertumbuhan ekonomi. Pada tahun 1957 pemerintah telah mengeluarkan Undang-Undang Nomor 22 Tahun 1957 tentang Penyelesaian Perselisihan Perburuhan dengan harapan melalui diundangkannya undang-undang tersebut akan dapat membatasi pemogokan yang banyak terjadi pada saat itu, dan diharapkan akan terwujud keseimbangan dan kedamaian industrial. Yang dengan UndangUndang Nomor 22 Tahun 1957 tersebut dibentuk sistem arbitrase wajib melalui P4 (Panitia Penyelesaian Perselisihan Perburuhan). Dengan 
Undang-Undang Nomor 22 Tahun

meningkat dan kompleks, sehingga 1957 tersebut nyatanya pemerintah berhasil untuk meredam mogok pekerja/ buruh, meskipun pihak pengusaha/ majikan dalam posisi yang cukup direpotkan karena sering diwarnai kebijakan untuk kenaikan upah karena tuntutan pekerja/ buruh ditengah inflasi yang tinggi. ${ }^{19}$

Walaupun pemerintah telah melakukan berbagai upaya untuk hubungan harmonis antara pekerja/ buruh dengan pengusaha/ majikan tapi karena banyak kendala yang dihadapi maka untuk optimalisasi dan realisasinya masih perlu waktu dan kerja keras lagi. Dalam rangka reformasi hukum ketenagakerjaan, pemerintah telah mengundangkan tiga buah undang-undang, yaitu UndangUndang Nomor 21 Tahun 2000 tentang Serikat Pekerja/ Serikat Buruh, Undang-Undang Nomor 13 Tahun 2003 tentang Ketenagakerjaan, dan Undang-Undang Nomor 2 Tahun 2004 tentang Penyelesaian Perselisihan Hubungan Industrial. ${ }^{20}$

Sementara itu, di era industrialisasi masalah perselisihan hubungan industrial semakin

\footnotetext{
${ }^{19}$ Suherman Toha, dkk, Op.cit, hal 42.

${ }^{20}$ Ibid.
} penyelesaian hubungan industrial yang cepat, tepat, adil, dan murah, harmonis, dinamis, serta berkeadilan, sehingga perlu ditetapkan model penyelesaian perselisihan hubungan industrial yang diatur dengan undangundang yang dapat mengakomodir penyelesaian semua bentuk perselisihan hubungan industrial, baik secara litigasi maupun non litigasi, seperti halnya dalam hubungan industrial apabila terjadi perselisihan. Oleh karena itu, lahirnya UndangUndang Nomor 2 Tahun 2004 tentang Penyelesaian Perselisihan Hubungan Industrial merupakan jawaban atas perbedaan pendapat yang mengakibatkan pertentangan antara pekerja dengan pengusaha, karena adanya perselisihan hak, perselisihan kepentingan, perselisihan pemutusan hubungan kerja, maupun perselisihan antar serikat pekerja/ serikat buruh dalam satu perusahaan. ${ }^{21}$

$$
\text { Melalui Undang-Undang }
$$
Nomor 13 Tahun 2003, politik hukum

21 Ujang Charda S, Model Penyelesaian Perselisihan Hubungan Industrial Dalam Hukum Ketenagakerjaan Setealah Lahirnya Undang-Undang Nomor 2 Tahun 2004, Jurnal Wawasan Yuridika, Volume 1, Nomor 1 (Maret 2017) : 4. 


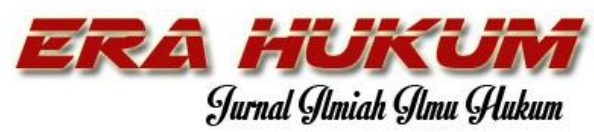

Vol. 16, No. 2, Oktober 2018

pemerintah bermaksud untuk membenahi aturan hukum

ketenagakerjaan/ hukum perburuhan materil agar adaptif dengan tuntutan kebutuhan masyarakat. Melalui Undang-Undang Nomor 2 Tahun 2004 tentang Penyelesaian Perselisihan Hubungan Industrial, pemerintah dalam hal ini pembentuk undangundang bermaksud untuk memperbaiki perihal soal-soal formal ketenagakerjaan/ perburuhan, yaitu mekanisme penyelesaian perselisihan sengketa hubungan industrial, yang tujuan utamanya adalah untuk pencerahan dalam mewujudkan keadilan dalam hal penyelesaian perselisihan hubungan industrial. ${ }^{22}$ Secara normatif Undang-Undang Nomor 2 Tahun 2004 ini ditujukan untuk memberikan perlindungan terhadap kepentingan pekerja/ buruh dalam hal penyelesaian perselisihan hubungan industrial melalui proses penyelesaian perselisihan yang adil, cepat, tepat dan murah.

\section{Bentuk Perwujudan Asas Keseimbangan Dalam Alternatif Penyelesaian}

${ }^{22}$ Ibid.
Usak Asas Keseimbangan Dalam Alternatif Penyelesaian Sengketa...

\section{Sengketa Hubungan Industrial di Luar Pengadilan}

Secara umum Undang-Undang Nomor 13 Tahun 2003 tentang Ketenagakerjaan, menganut penyelesaian sengketa atau perselisihan didasarkan atas prinsip musyawarah untuk mufakat ${ }^{23}$, yang berarti bahwa setiap perselisihan antara pekerja dan pengusaha harus diselesaikan melalui suatu mekanisme yang damai berdasarkan asas keseimbangan antara pekerja dan pengusaha. Untuk lebih menjamin terciptanya asas keseimbangan dan rasa keadilan bagi pihak yang beperkara, menurut UU No 2 Tahun 2004, penyelesaian sengketa diutamakan melalui perundingan guna mencari musyawarah mufakat di luar pengadilan. $^{24}$ Hal ini akan menciptakan asas keseimbangan bagi posisi para pihak sekaligus memberikan perlindungan hukum. Ada empat bentuk perwujudan asas keseimbangan yang dapat dilakukan dalam alternatif penyelesaian sengketa hubungan industrial di luar

\footnotetext{
${ }^{23}$ Pasal 136 ayat 1 Undang-Undang Nomor 13 Tahun 2003 Tentang Ketenagakerjaan.

${ }^{24}$ Pasal 3 ayat 1 Undang-Undang Nomor 2 Tahun 2004 tentang Penyelesaian Perselisihan Hubungan Industrial.
} 
pengadilan, yaitu melalui bipartit, konsiliasi, arbitrase, dan mediasi.

\section{Bipartit}

Bipartit adalah penyelesaian perselisihan atau perundingan antara pengusaha dan pekerja atau kuasa pekerja (serikat pekerja) di tingkat perusahaan. Setiap perundingan di tingkat bipartit ini wajib dibuat Risalah Perundingan yang memuat: nama lengkap dan alamat pihak beperkara; tanggal dan tempat perundingan; pokok masalah atau alasan perselisihan; pendapat para pihak beperkara; kesimpulan/hasil perundingan; tanggal dan tanda tangan kedua belah pihak yang melakukan perundingan.

Pengertian Bipartit dalam hal ini sebagai mekanisme adalah tata cara atau proses perundingan yang dilakukan antara dua pihak, yaitu pihak pihak pengusaha dengan pihak pekerja/buruh apabila terjadi perselisihan antara kedua belah pihak di perusahaan. Perundingan bipartit pada hakekatnya merupakan upaya musyawarah untuk mufakat antara pengusaha dan pihak pekerja/buruh. Lingkup penyelesaian perselisihan hubungan industrial melalui bipartit meliputi keempatjenis perselisihan, yakni perselisihan hak,perselisihan kepentingan, perselisihan PHK dan perselisihan antar serikat pekerja/serikat buruh dalam satu perusahaan. Upaya penyelesaian perselisihan hubungan industrial melalui perundingan secara musyawarah untuk mencapai mufakat antara pengusaha dengan pekerja yang dilandasi rasa kekeluargaan. ${ }^{25}$

Bilamana dalam perundingan ini terjadi kesepakatan, maka dibuat Perjanjian Bersama yang ditandatangani oleh kedua belah pihak beperkara. $^{26}$ Selanjutnya Perjanjian Bersama ini wajib didaftarkan di Perselisihan Hubungan Industrial guna memperoleh Akta Bukti Pendaftaran Perjanjian Bersama. Apabila ternyata kemudian salah satu pihak tidak melaksanakan kesepakatan dalam Perjanjian Bersama, pihak yang dirugikan hak perdatanya dapat mengajukan permohonan eksekusi kepada Pengadilan Hubungan Industrial di wilayah hukumnya. ${ }^{27}$

\footnotetext{
${ }^{25}$ Akbar Pradima, Alternatif Penyelesaian Sengeketa Hubungan Industrial Diluar Pengadilan, DIH, Jurnal Ilmu Hukum, Volume 9, Nomor 17 (Februari 2013) : 4

${ }^{26}$ Pasal 7 ayat 1 Undang-Undang Nomor 2 Tahun 2004 tentang Penyelesaian Perselisihan Hubungan Industrial.

27 Pasal 7 ayat 5 Undang-Undang Nomor 2 Tahun 2004 tentang Penyelesaian Perselisihan Hubungan Industrial.
} 
Penyelesaian perselisihan

melalui Bipartit ini harus tuntas paling lama 30 hari sejak tanggal perundingan. ${ }^{28}$ Bilamana dalam jangka waktu 30 hari perundingan buntu (deadlock) atau salah satu pihak yang beperkara menolak untuk berunding, maka perundingan bipartit dianggap gagal. ${ }^{29}$ Apabila dalam perundingan bipartit gagal, maka salah satu atau kedua belah pihak mencatatkan perselisihannya kepada Dinas Tenaga Kerja (Disnaker) setempat dengan melampirkan bukti upaya penyelesaian bipartit. $^{30}$ Selanjutnya, Disnaker menawarkan kepada para pihak beperkara untuk memilih penyelesaian melalui konsiliasi atau arbitrase. ${ }^{31}$ Namun apabila pihak yang beperkara tidak menetapkan pilihan melalui konsiliasi atau arbitrase, Disnaker melimpahkan penyelesaiannya melalui mediasi. ${ }^{32}$

\footnotetext{
28 Pasal 3 ayat 2 Undang-Undang Nomor 2 Tahun 2004 tentang Penyelesaian Perselisihan Hubungan Industrial.

29 Pasal 3 ayat 3 Undang-Undang Nomor 2 Tahun 2004 tentang Penyelesaian Perselisihan Hubungan Industrial.

${ }^{30}$ Pasal 4 ayat 1 Undang-Undang Nomor 2 Tahun 2004 tentang Penyelesaian Perselisihan Hubungan Industrial.

31 Pasal 4 ayat 3 Undang-Undang Nomor 2 Tahun 2004 tentang Penyelesaian Perselisihan Hubungan Industrial.

32 Pasal 4 ayat 4 Undang-Undang Nomor 2 Tahun 2004 tentang Penyelesaian Perselisihan Hubungan Industrial.
}

\section{Mediasi}

Mediasi, adalah penyelesaian perselisihan antara pengusaha dan pekerja atau kuasa pekerja yang diperantarai mediator atau Pegawai Departemen Tenaga Kerja yang ditunjuk Menteri Tenaga Kerja dan Transmigrasi RI. Dulu, disebut Tingkat Tripartit atau Tingkat Perantaraan. Lembaga ini merupakan penyelesaian terakhir di luar pengadilan, apabila salah satu atau para pihak beperkara tidak dapat menetapkan pilihan konsiliasi atau arbitrase, atau menolak penyelesaian perselisihan melalui konsiliasi atau arbitrase.

Dalam hal tercapai kesepakatan penyelesaian perselisihan hubungan industrial melalui mediasi, maka dibuat Perjanjian Bersama yang ditandatangani oleh para pihak dan disaksikan oleh mediator serta didaftar di Pengadilan Hubungan Industrial pada Pengadilan Negeri di wilayah hukum pihak-pihak mengadakan Perjanjian Bersama untuk mendapatkan akta bukti pendaftaran. ${ }^{33}$ Dalam hal tidak tercapai kesepakatan

\footnotetext{
${ }^{33}$ Pasal 13 ayat 1 Undang-Undang Nomor 2 Tahun 2004 tentang Penyelesaian Perselisihan Hubungan Industrial.
} 
penyelesaian perselisihan hubungan industrial melalui mediasi, maka: ${ }^{34}$

a. mediator mengeluarkan anjuran tertulis;

b. anjuran tertulis sebagaimana dimaksud pada huruf a dalam waktu selambat-lambatnya 10 (sepuluh) hari kerja sejak sidang mediasi pertama harus sudah disampaikan kepada para pihak;

c. para pihak harus sudah memberikan jawaban secara tertulis kepada mediator yang isinya menyetujui atau menolak anjuran tertulis dalam waktu selambat-lambatnya 10 (sepuluh) hari kerja setelah menerima anjuran tertulis;

d. pihak yang tidak memberikan pendapatnya sebagaimana dimaksud pada huruf c dianggap menolak anjuran tertulis;

e. dalam hal para pihak menyetujui anjuran tertulis sebagaimana dimaksud pada huruf a, maka dalam waktu selambat-lambatnya 3 (tiga) hari kerja sejak anjuran tertulis disetujui, mediator harus sudah selesai membantu para

\footnotetext{
${ }^{34}$ Krista Yitawati, Penyelesaian Perselisihan Hubungan Industrial Melalui Mediasi, Jurnal Yustisia Merdeka, Volume 3, Nomor 1 (Maret 2017) : 76.
}

pihak membuat Perjanjian

Bersama untuk kemudian didaftar di Pengadilan Hubungan Industrial pada Pengadilan Negeri di wilayah hukum pihak-pihak mengadakan Perjanjian Bersama untuk mendapatkan akta bukti pendaftaran.

Penyelesaian perselisihan melalui mediasi ini dalam jangka waktu paling lambat 30 hari kerja, terhitung sejak menerima pelimpahan penyelesaian perselisihan dari salah satu pihak atau para pihak di Tingkat Bipartit/Konsiliasi/Arbitrase. ${ }^{35}$

3. Konsiliasi

Konsiliasi adalah penyelesaian perselisihan kepentingan, perselisihan pemutusan hubungan kerja (PHK), dan perselisihan antarserikat pekerja dalam satu perusahaan yang dilakukan melalui musyawarah yang ditengahi oleh seorang atau lebih konsiliator yang netral. Penyelesaian perselisihan melalui konsiliasi dilakukan oleh konsiliator yang terdaftar pada kantor instansi yang bertanggung

\footnotetext{
35 Pasal 15 Undang-Undang Nomor 2 Tahun 2004 tentang Penyelesaian Perselisihan Hubungan Industrial.
} 
jawab di bidang ketenagakerjaan

Kabupaten/Kota. Konsiliator

adalah lembaga perorangan atau

swasta mandiri yang diangkat dan

diberhentikan dalam periode

tertentu melalui Keputusan

Menteri Tenaga Kerja dan

Transmigrasi RI. Fungsi lembaga ini adalah menerima jasa bantuan/pelayanan hukum bidang ketenagakerjaan dari salah satu pihak atau pihak beperkara yang mengajukan permohonan penyelesaian secara tertulis, terutama perselisihan hak, kepentingan antara pengusaha dan pekerja, Pemutusan Hubungan Kerja (PHK). Setiap jasa bantuan hukum yang diberikan oleh lembaga konsiliasi ini dibayar oleh Negara, yang besarnya ditentukan oleh Menteri Tenaga Kerja dan Transmigrasi RI. ${ }^{36}$

Tugas konsiliator melakukan konsiliasi dengan mengupayakan musyawarah untuk mencapai mufakat, bila dalam perundingan mencapai kesepakatan dituangkan dalam bentuk perjanjian bersama ditandatangani oleh kedua belah

36 Pasal 26 Undang-Undang Nomor 2 Tahun 2004 tentang Penyelesaian Perselisihan Hubungan Industrial. pihak dan disaksikan oleh konsiliator dan selanjutnya mendaftarkan perjanjian bersama tersebut untuk memperoleh bukti pendaftaran, apabila perjanjian bersama yang disepakati dan sudah didaftarkan tersebut tidak dipatuhi oleh para pihak maka dapat mengajukan permohonan eksekusi kepada PHI. ${ }^{37}$

Lembaga konsiliasi menyelesaikan perselisihan hubungan industrial melalui musyawarah, tetapi apabila tidak tercapai, maka konsiliator akan mengeluarkan anjuran yang berisi pendapat konsiliator atas perselisihan yang dihadapkan kepadanya. $^{38}$ Pendapat yang dikeluarkan oleh konsiliator tersebut hanya berupa anjuran dan bukan putusan, maka para pihak yang terkait dalam perselisihan tersebut tidak wajib memenuhi anjuran. Pihak yang merasa dirugikan atas anjuran tersebut berhak menolak melaksanakan isi

37 Suhandi, Karakteristik Penyelesaian Perselisihan Hubungan Industrial Melalui Pengadilan Hubungan Industrial, Jurnal Perspektif, Volume 22, Nomor 2 (Mei 2017) : 167.

38 Pasal 23 ayat 2 Undang-Undang Nomor 2 Tahun 2004 tentang Penyelesaian Perselisihan Hubungan Industrial. 
anjuran dan mengajukan gugatan

ke Pengadilan Hubungan

Industrial. $^{39} \quad$ Penyelesaian

perselisihan melalui konsiliasi ini

harus tuntas dalam waktu 30 hari

kerja, terhitung sejak menerima

permintaan dari salah satu pihak

atau para pihak yang beperkara

dalam satu perusahaan.

\section{Arbitrase}

Penyelesaian perselisihan hubungan industrial melalui arbitrase dilakukan atas dasar kesepakatan para pihak, putusan arbitrase bersifat final dan tetap, tidak dapat diajukan gugatan ke PHI (Pengadilan Hubungan Industrial), terkecuali bila dalam hal-hal tertentu dapat dilakukan pembatalan ke MA (Mahkamah Agung) RI. Arbiter diangkat berdasarkan Keputusan Menteri Ketenagakerjaan. ${ }^{40}$ Penyelesaian perselisihan hubungan industrial melalui arbiter dilakukan atas

39 Pasal 24 ayat 1 Undang-Undang Nomor 2 Tahun 2004 tentang Penyelesaian Perselisihan Hubungan Industrial

40 Pasal 30 ayat 1 Undang-Undang Nomor 2 Tahun 2004 tentang Penyelesaian Perselisihan Hubungan Industrial. dasar kesepakatan para pihak yang berselisih. ${ }^{41}$

Penyelesaian perselisihan hubungan industrial melalui arbitrase hubungan industrial yang dilakukan oleh arbiter harus diawali dengan upaya mendamaikan kedua belah pihak yang berselisih. $^{42}$ Apabila perdamaian tersebut tercapai, maka arbiter atau majelis arbiter wajib membuat akta perdamaian yang ditandatangani oleh para pihak yang berselisih dan arbiter. Akta perdamaian sebagaimana dimaksud di atas didaftarkan di Pengadilan Hubungan Industrial pada Pengadilan Negeri di wilayah arbiter mengadakan perdamaian. ${ }^{43}$

Pendaftaran akta perdamaian dilakukan sebagai berikut: ${ }^{44}$

a. Akta Perdamaian yang telah didaftar diberikan akta bukti pendaftaran dan merupakan

${ }^{41}$ Pasal 32 ayat 1 Undang-Undang Nomor 2 Tahun 2004 tentang Penyelesaian Perselisihan Hubungan Industrial.

${ }^{42}$ Pasal 44 ayat 1 Undang-Undang Nomor 2 Tahun 2004 tentang Penyelesaian Perselisihan Hubungan Industrial.

43 Pasal 44 ayat 3 Undang-Undang Nomor 2 Tahun 2004 tentang Penyelesaian Perselisihan Hubungan Industrial.

${ }^{44}$ Pasal 44 ayat 4 Undang-Undang Nomor 2 Tahun 2004 tentang Penyelesaian Perselisihan Hubungan Industrial. 
bagian yang tidak terpisahkan

Penyelesaian perselisihan dari Akta Perdamaian;

b. apabila Akta Perdamaian tidak dilaksanakan oleh salah satu pihak, maka pihak yang dirugikan dapat mengajukan permohonan eksekusi kepada Pengadilan Hubungan Industrial pada Pengadilan Negeri di wilayah Akta Perdamaian didaftar untuk mendapat penetapan eksekusi;

c. dalam hal pemohon eksekusi berdomisili di luar wilayah hukum Pengadilan Hubungan Industrial pada Pengadilan Negeri tempat pendaftaran Akta Perdamaian, maka pemohon eksekusi dapat mengajukan permohonan eksekusi melalui Pengadilan Hubungan Industrial pada Pengadilan Negeri di wilayah domisili pemohon eksekusi untuk diteruskan ke Pengadilan Hubungan Industrial pada Pengadilan Negeri yang berkompeten

melaksanakan eksekusi.

Apabila ada pihak yang merasa dirugikan oleh putusan arbitrase, satusatunya yang dapat dilakukan adalah mengajukan permohonan pembatalan putusan arbitrase ke Mahkamah Agung melalui upaya hukum peninjauan kembali. Upaya tersebut harus sudah diajukan selambatlambatnya 30 hari terhitung sejak dikeluarkannya putusan arbitrase. Adapun alasan pengajuan perjanjian kembali adalah apabila putusan diduga

45 Pasal 51 ayat 1 Undang-Undang Nomor 2 Tahun 2004 tentang Penyelesaian Perselisihan Hubungan Industrial. 
mengandung unsur-unsur sebagai berikut: ${ }^{46}$

a. surat atau dokumen yang diajukan dalam pemeriksaan, setelah putusan dijatuhkan, diakui atau dinyatakan palsu;

b. setelah putusan diambil ditemukan dokumen yang bersifat menentukan, yang disembunyikan oleh pihak lawan;

c. putusan diambil dari tipu muslihat yang dilakukan oleh salah satu pihak dalam pemeriksaan perselisihan;

d. putusan melampaui kekuasaan arbiter hubungan industrial; atau

e. putusan bertentangan dengan peraturan perundang-undangan.

Dalam jangka waktu 30 hari setelah pengajuan permohonan pembatalan, Mahkamah Agung harus mengeluarkan putusan. Putusan yang dikeluarkan dapat menerima permohonan pembatalan dan dapat juga menolak. Apabila diterima, maka putusan arbitrase sebelumnya akan dibatalkan dengan menyebut akibat hukum dari pembatalan.

Pengusaha dan pekerja memiliki peran sentral dalam

\footnotetext{
${ }^{46}$ Pasal 52 ayat 1 Undang-Undang Nomor 2 Tahun 2004 tentang Penyelesaian Perselisihan Hubungan Industrial.
}

menjalankan

perusahaan.

Keseimbangan hubungan para pihak menjadi salah satu kunci utama dalam menjaga roda industri agar bisa berjalan secara normal. John Rawls ${ }^{47}$ menyatakan bahwa prinsip-prinsip keseimbangan diperoleh bukan dengan mengevaluasi kemanfaatan dari tindakan-tindakan melainkan dari pilihan rasional di dalam kondisi adil. Melalui Undang-Undang Nomor 2 Tahun 2004 tentang Penyelesaian Perselisihan Hubungan Industrial, pemerintah dalam hal ini pembentuk undang-undang telah mengatur mekanisme alternatif penyelesaian sengketa hubungan industrial di luar pengadilan, yang tujuan utamanya adalah untuk mewujudkan asas keseimbangan dalam hal penyelesaian perselisihan hubungan industrial di luar pengadilan yang merupakan pilihan rasional para pihak di dalam kondisi adil dan seimbang.

Keberadaan asas

keseimbangan difungsikan untuk memproses, menganalisis dan mengarahkan perubahan-perubahan struktural dan intitusional tersebut agar gejolak tidak sehat dalam dunia usaha dapat dikendalikan dan menjadi

${ }^{47}$ Karen Lebacqz, Op.cit, hal. 49-79. 


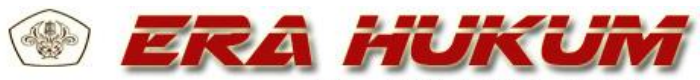 \\ Vol. 16, No. 2, Oktober 2018}

tertib kembali. Keseimbangan yang terjadi mengakibatkan tegaknya keadilan dan kepastian hukum. Negara memiliki peranan dalam penyelesaian sengketa hubungan industrial dalam rangka menjaga hubungan hukum yang terjadi, dalam batas-batas asas keseimbangan kepentingan umum bagi semua pihak. Peranan negara dalam hal ini adalah dalam rangka menjaga keseimbangan kepentingan semua pihak dalam masyarakat, melindungi kepentingan pekerja/buruh dan pengusaha/perusahaan dan melindungi kepentingan negara dan kepentingan umum, terhadap kepentingan perusahaan atau pribadi. ${ }^{48}$

\section{Penutup}

\section{A. Kesimpulan}

Perselisihan hubungan industrial antara pekerja atau buruh dan pengusaha sering kali terjadi sebagai akibat dari ketidaksesuaian pendapat dan atau tindakan keduanya. Perselisihan keduanya biasanya didahului adanya pelanggaran hukum dan bisa juga terjadi bukan karena pelanggaran hukum. Untuk perihal lembaga yang tepat untuk

48 Sri Rejeki, Hukum Ekonomi Indonesia, (Malang: Bayu Media, 2007), 13.
Asas Keseimbangan Dalam Alternatif Penyelesaian Sengketa...

penyelesaian sengketa hubungan industrial, apabila dilandasi pola pemikiran asas keseimbangan adalah musyawarah mencari penyelesaian sengketa, maka lembaga yang tepat adalah lembaga non litigasi di luar pengadilan, tanpa harus digiring ke Pengadilan Hubungan Industrial.

Untuk lebih menjamin terciptanya asas keseimbangan dan rasa keadilan bagi pihak yang beperkara, UU No 2 Tahun 2004 telah mengamanatkan penyelesaian sengketa diutamakan melalui perundingan guna mencari musyawarah mufakat di luar pengadilan. Hal ini akan menciptakan asas keseimbangan bagi posisi para pihak sekaligus memberikan perlindungan hukum. Ada empat bentuk perwujudan asas keseimbangan yang dapat dilakukan dalam alternatif penyelesaian sengketa hubungan industrial di luar pengadilan, yaitu melalui bipartit, konsiliasi, arbitrase, dan mediasi. Jika melalui upaya mediasi, konsolidasi, maupun arbitrase mengalami kegagalan, maka salah satu pihak dapat mengajukan gugatan ke Pengadilan Hubungan Industrial dan apabila putusan pengadilan dirasa belum memenuhi rasa keadilan, maka 
para pihak dapat mengajukan upaya

hukum kasasi di Mahkamah Agung.

\section{B. Saran}

Dengan adanya lembaga alternatif penyelesaian sengketa dalam hubungan industrial memberikan kemudahan bagi para pihak untuk menyelesaikan sengketa yang diakibatkan perselisihan antara pemberi kerja dengan pekerja/buruh, sehingga dalam penyelesaian sengeketa tersebut terdapat keseimbangan dalam proses penyelesaian sengketa dalam hubungan industrial untuk kepentingan semua pihak.

Negara memiliki peranan dalam penyelesaian sengketa hubungan industrial dalam rangka menjaga hubungan hukum yang terjadi, dalam batas-batas asas keseimbangan kepentingan umum bagi semua pihak. Peranan negara dalam hal ini adalah dalam rangka menjaga keseimbangan kepentingan semua pihak dalam masyarakat. Pemerintah mengatur mekanisme alternatif penyelesaian sengketa hubungan industrial di luar pengadilan, yang tujuan utamanya adalah untuk mewujudkan asas keseimbangan dalam hal penyelesaian perselisihan hubungan industrial di luar pengadilan yang merupakan pilihan rasional para pihak di dalam kondisi adil dan seimbang.

\section{Daftar Pustaka}

Buku

Apeldoorn, L.J. Van, Pengantar Ilmu Hukum, Jakart: Pradnya Paramita, 1983.

Cotterrell, Roger, The Sociology of Law: An Introduction, London: Butterworths, 1992.

Hernoko, Agus Yudha, Hukum Perjanjian Asas Proposionalitas dalam Kontrak Komersial, Jakarta: Kencana Prenada Media Group, 2010.

Huijbers, Theo, Filsafat Hukum Dalam Lintasan Sejarah, Yogyakarta: Kanisius, 1986.

Husni, Lalu, Hukum Ketenagakerjaan Indonesia, Jakarta: Raja Grafindo Persada, 2007.

Lebacqz, Karen, Teori-teori Keadilan (Six Theories of Justice), Bandung: Nusa Media, 1986.

Mahmud, Peter Marzuki, Penelitian Hukum, Jakarta: Penerbit Kencana Prenada Media Group, 2005.

Maimun, Hukum Ketenagakerjaan Suatu Pengantar, Jakarta: PT Pradnya Paramita, 2007.

Poerwadarminta, WJS, Kamus Umum Bahasa Indonesia, Jakarta: PN.Balai Pustaka,1976. 
Rejeki, Sri, Hukum Ekonomi Indonesia, Malang: Bayu Media, 2007.

Soepomo, Imam, Hukum Perburuhan Bidang Hubungan Kerja, Jakarta: Penerbit Jambatan, 1975.

Toha, Suherman, dkk, Laporan Akhir Penelitian Hukum Tentang Penyelesaian Perselisihan Hubungan Industrial, Jakarta: Badan Pembinaan Hukum Nasional Kementerian Hukum Dan Ham RI, 2010.

\section{Peraturan Perundang-undangan}

Undang-Undang Dasar NKRI Tahun 1945.

S, Ujang Charda, Model Penyelesaian Perselisihan Hubungan Industrial Dalam Hukum Ketenagakerjaan Setealah Lahirnya Undang-Undang Nomor 2 Tahun 2004. Jurnal Wawasan Yuridika. Volume 1, Nomor 1 (Maret 2017), 4.

Suhandi, Karakteristik Penyelesaian Perselisihan Hubungan Industrial Melalui Pengadilan Hubungan Industrial. Jurnal Perspektif. Volume 22, Nomor 2 (Mei 2017). 167.

Yitawati, Krista, Penyelesaian Perselisihan Hubungan Industrial Melalui Mediasi. Jurnal Yustisia Merdeka. Volume 3, Nomor 1 (Maret 2017) : 76 .

Undang-Undang Nomor 13 Tahun $2003 \quad$ Tentang

Ketenagakerjaan.

Undang-Undang Nomor 2 Tahun 2004 tentang Penyelesaian Perselisihan Hubungan Industrial.

\section{Jurnal}

Harijanto, "Analisis Terhadap Alternatif Penyelesaian Sengketa (APS) Ditinjau Dari Sosiologi Hukum." Jurnal Rechtens. Volume 1, Nomor 2 (Desember 2014): 57.

Pradima, Akbar, Alternatif Penyelesaian Sengeketa Hubungan Industrial Diluar Pengadilan. DIH Jurnal Ilmu Hukum. Volume 9, Nomor 17 (Februari 2013): 4. 